International Conference on Ceramics, Bikaner, India

International Journal of Modern Physics: Conference Series

Vol. 22 (2013) 71-78

(C) World Scientific Publishing Company

DOI: $10.1142 / \mathrm{S} 201019451300994 \mathrm{X}$

\title{
USE OF CERAMIC MATERIAL (CEMENT CLINKER) FOR THE PRODUCTION OF BIODIESEL
}

\author{
SUNNY SONI*, MADHU AGARWAL \\ Department of Chemical Engineering, \\ Malaviya National Institute of Technology Jaipur, \\ J.L.N. Marg, Jaipur-302017, India \\ Authore-mail: sunny.soni371@gmail.com,madhunaresh@gmail.com.
}

\begin{abstract}
Biodiesel is a renewable liquid fuel made from natural, renewable biological sources such as edible and non edible oils. Over the last years, biodiesel has gained more market due to its benefits and because it appears as the natural substitute for diesel. Reasons for growing interest in biodiesel include its potential for reducing noxious emissions, potential contributions to rural economic development, as an additional demand center for agricultural commodities, and as a way to reduce reliance on foreign oil. Biodiesel was prepared from soybean oil by transesterification with methanol in the presence of cement clinker. Cement clinker was examined as a catalyst for a conversion of soybean oil to fatty acid methyl esters (FAMEs). It can be a promising heterogeneous catalyst for the production of biodiesel fuels from soybean oil because of high activity in the conversion and no leaching in the transesterification reaction. The reaction conditions were optimized. A study for optimizing the reaction parameters such as the reaction temperature, and reaction time, was carried out. The catalyst cement clinker composition was characterized by XRF. The results demonstrate that the cement clinker shows high catalytic performance \& it was found that the yield of biodiesel can reach as high as $84.52 \%$ after $1 \mathrm{~h}$ reaction at $65^{\circ} \mathrm{C}$, with a $6: 1$ molar ratio of methanol to oil, $21 \mathrm{wt} \% \mathrm{KOH} /$ cement clinker as catalyst.
\end{abstract}

Keywords: cement clinker; biodiesel; transesterification; soybean oil.

\section{Introduction}

The world energy demand is increasing rapidly due to increase in population and industrialization that limited reservoirs will soon be depleted at the current rate of consumption. Diesel fuel has an essential function in the industrial economy of a developing country and is used in transports, industrial and agricultural goods, etc. Interest in renewable fuels has increased substantially in recent years ${ }^{1}$. An alternative fuel should be easily available, environment friendly and techno-economically competitive. One of such fuels is triglycerides and their derivatives ${ }^{2}$. Biodiesel, as renewable and biological origin alternative diesel fuel, has been receiving a lot of concern throughout the world due to the energy needs and environmental awareness ${ }^{3}$.Therefore the alternative fuel diesel engines have gained attention all over the world. Biodiesel is defined as the mono alkyl esters of long chain fatty acids derived from renewable feed stock, such as vegetable oil or animal fats, for use in compression ignition engines ${ }^{4}$. The 
plant oils usually contain free fatty acids, phospholipids, sterols, water, odorants and other impurities. Because of these the oil cannot be used as fuel directly. To overcome these problem the oil requires slight chemical modification mainly transesterification, pyrolysis and emulsification. Among these, Transesterification is one of the most commercially useable methods to produce biodiesel and the process involves a reaction between ester (here triglyceride) and alcohol to form new ester and alcohol. Different types of alcohols such as, methanol, ethanol, propanol and butanol have been used. However, methanol and ethanol are the most widely used, particularly methanol owing to its low price and availability ${ }^{5}$. In the transesterification of triglyceride to fatty acid alkyl esters three reversible reactions take place consecutively in which diglycerides and monoglycerides are major intermediate products (Fig. 1) ${ }^{3}$.

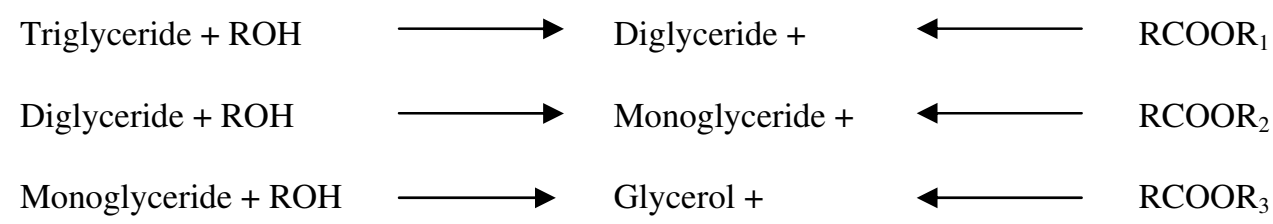

Figure 1. Transesterification of triglyceride to fatty acid alkyl esters ${ }^{3}$

Transesterification reaction can be either carried out via non-catalytic or catalytic processes. Catalyst used for the transesterification of triglycerides is classified as alkali, acid, enzyme or heterogeneous catalysts. Enzymatic base production of biodiesel has attracted many attention in recent years since enzymes tolerate free fatty acid and water contents in the oil to avoid soap formation and thus purification of biodiesel and glycerol is easier ${ }^{7,8}$. However, enzymes are expensive to be used in a commercial production of biodiesel. Significant amounts of work have been carried out on homogeneous acid and base catalysis transesterification of vegetable oils. If the oil has high free acid content and more water, acid catalyst is suitable. Sulphuric acid and hydrochloric acid are normally used as acid catalysts since these catalysts are capable to handle esterification and transesterification of triglyceride simultaneously. Nonetheless, the process requires a high molar ratio of alcohol to oil and long reaction time ${ }^{9}$. Besides that, under these conditions all the equipment need to withstand against corrosion due to an acidity environment ${ }^{10}$. Alkali metal alkoxides are most effective Transesterification catalyst compared to the acid catalyst. Sodium alkoxides are the mostly efficient catalysts, although $\mathrm{KOH}$ and $\mathrm{NaOH}$ can also be used ${ }^{11,12}$. Trans methylation occurs approximately 4000 times faster in presence of an alkaline catalyst than the same amount of acidic catalyst ${ }^{13}$. As they are less corrosive to industrial equipments, alkaline catalysts are preferred in industrial processes. The concentration in the range of $0.5-1.0 \%(\mathrm{w} / \mathrm{w})$ has found to yield $94-99 \%$ conversion of vegetable oils into ester and further increase of catalyst concentration does not affect the conversion but add to extra cost, as the catalyst needs to be removed from the reaction mixture after completion of reaction ${ }^{14-16}$. The transesterification can be performed in a shorter reaction time and relatively modest operation conditions ${ }^{17}$. In spite 
of this, the water and free fatty acids content in the oil need to be very low because of the probability of soap formation which can consume catalyst thus reducing the methyl ester yields. Conventional synthesis techniques rely on soluble sodium and potassium hydroxide catalysts; however, removal of these catalysts is technically difficult and brings extra cost to the final product ${ }^{18}$. Besides, the process is not environmentally friendly because a large amount of waste water is produced in the separation step ${ }^{19}$. However, the cost of biodiesel could certainly be lowered by improving the production processes $^{20}$. The first step in this direction could be represented by the use of heterogeneous catalysts instead of homogeneous ones. Heterogeneous catalysts can be more easily separated and give place to higher quality of ester products and glycerol by product. Pure high grade glycerol can be obtained, in this case, without expensive refining operations. For these reasons, many heterogeneous catalysts, based on Metal hydroxides ${ }^{21}$, metal complexes ${ }^{22}$, metal oxides such as calcium oxide ${ }^{23}$, magnesium oxide $^{24}$, zirconium oxide ${ }^{25}$ and supported catalysts ${ }^{26}$ have been investigated as solid catalysts. The catalysts are not consumed or dissolved in the reaction and therefore can be easily separated from the products. As a result, the products do not contain impurities of the catalyst and the cost of final separation could be reduced. The catalysts can also be readily regenerated and reused and it is more environmentally benign because there is no need for acid or water treatment in the separation $\operatorname{step}^{27}$. Studies have been carried out to synthesize and develop new solid catalysts for transesterification reaction in order to overcome disadvantages of use of homogeneous catalyst and more likely to reduce the cost of biodiesel production.

In the present work the catalytic performances of cement clinker catalyst in the transesterification reaction of soybean oil with methanol have been studied. Methanolysis of soybean oil was carried out with $21 \mathrm{wt} \% \mathrm{KOH} /$ cement clinker as a catalyst at $65{ }^{\circ} \mathrm{C}$ with $\mathrm{MeOH} / \mathrm{oil}$ molar ratio of $6: 1$. The reaction yield in the temperature range $65^{\circ} \mathrm{C}$ was about $85 \%$ in $1 \mathrm{~h}$.

\section{Experimental}

\section{Materials}

Soybean oil used for the preparation of biodiesel was purchased from jaipur. $\mathrm{CH}_{3} \mathrm{OH}$, $\mathrm{KOH} \&$ all the chemicals were purchased from companies Ranbaxy fine chemicals (Renkem) Laboratory, Hi-media Laboratory Limited \& MERCK Limited. The Cement clinker was collected from J.K. Lakshmi Cement Ltd., Jaykaypuram-Sirohi (Rajasthan).

The quality of oil is expressed in terms of the physicochemical properties such as acid value, Specific gravity, Kinematic viscosity, etc. These properties of soybean oil (without further treatment) were determined as per Bureau of Indian Standard which have shown in Table 1. 
Table 1. Characterization of soybean oil

\begin{tabular}{ccc}
\hline S.NO. & Parameters & Soybean oil \\
\hline 1 & Acid value $(\mathrm{mg} \mathrm{KOH} / \mathrm{g})$ & 2.4 \\
2 & Free fatty acid $(\mathrm{mg} \mathrm{KOH} / \mathrm{g})$ & 2.09 \\
3 & Kinematic viscosity $\left(\mathrm{cSt}\right.$ at $\left.40^{\circ} \mathrm{C}\right)$ & 31.6 \\
4 & Density $(\mathrm{kg} / \mathrm{l})$ & 0.843 \\
5 & Specific gravity $\left(\right.$ at $\left.26^{0} \mathrm{C}\right)$ & 0.9125 \\
6 & Pour point $\left({ }^{0} \mathrm{C}\right)$ & -8 \\
7 & Cloud point $\left({ }^{0} \mathrm{C}\right)$ & -2 \\
8 & Flash point $\left({ }^{\circ} \mathrm{C}\right)$ & 265 \\
9 & Fire point $\left({ }^{\circ} \mathrm{C}\right)$ & 270 \\
\hline
\end{tabular}

\section{Catalyst preparation}

The characterization of cement clinker has been done by XRF at JK Lakshmi Cement Ltd., which have shown in Table 2. The clinker was first dried at $100{ }^{\circ} \mathrm{C}$ for $12 \mathrm{hrs}$ to remove moisture. After that, it was crushed with a grinder and sieved to a particle size of $1.8-2.8 \mathrm{~mm}$. $15 \mathrm{gm}$ of clinker were taken in a beaker \& $4 \mathrm{gm}$ of aq. $\mathrm{KOH}$ solution was mixed drop by drop while stirring and heating continuously for making paste. This paste was dried in oven at $100^{\circ} \mathrm{C}$ for a night. Thereafter, the dried powder was calcinated at $650^{\circ} \mathrm{C}$ for $3 \mathrm{hrs}$. The catalyst, thus, obtained with $\mathrm{KOH}$ loading as $21 \mathrm{wt} \% \mathrm{KOH} / \mathrm{Clinker}$.

Table 2. Characterization of cement clinker

\begin{tabular}{lll}
\hline S.NO. & $\mathrm{Content}$ & $\%$ \\
\hline 1 & $\mathrm{Na}_{2} \mathrm{O}$ & 0.37 \\
2 & $\mathrm{MgO}$ & 3.03 \\
3 & $\mathrm{Al}_{2} \mathrm{O}_{3}$ & 5.72 \\
4 & $\mathrm{SiO}_{2}$ & 20.99 \\
5 & $\mathrm{SO}_{3}$ & 1.29 \\
6 & $\mathrm{Cl}^{\ominus}$ & - \\
7 & $\mathrm{~K}_{2} \mathrm{O}$ & 0.69 \\
\hline 8 & $\mathrm{CaO}$ & 63.98 \\
9 & $\mathrm{TiO}_{2}$ & - \\
10 & $\mathrm{Fe} \mathrm{O}_{3}$ & 3.71 \\
11 & $\mathrm{~A} / \mathrm{F}$ & 1.54 \\
12 & $\mathrm{~S} / \mathrm{R}$ & 2.23 \\
13 & LSF & 94 \\
14 & $\mathrm{~F} / \mathrm{CaO}$ & 1.84 \\
15 & Tricalcium Silicate $\left(\mathrm{Ca}_{3} \mathrm{SiO}_{5}\right), \mathrm{C}_{3} \mathrm{~S}$ & 46.11 \\
16 & Dicalcium Silicate $\left(\mathrm{Ca}_{2} \mathrm{SiO}_{4}\right), \mathrm{C}_{2} \mathrm{~S}$ & 25.4 \\
17 & Tricalcium Aluminate $\left(\mathrm{Ca}_{3} \mathrm{Al}_{2} \mathrm{O}_{6}\right), \mathrm{C}_{3} \mathrm{~A}$ & 8.87 \\
18 & Tetracalcium Aluminoferrite $\left(\mathrm{Ca}_{2} \mathrm{AlFeO}\right), \mathrm{C}_{4} \mathrm{AF}$ & 11.3 \\
19 & Liquid & 28.1 \\
\hline & & \\
\hline
\end{tabular}




\section{Reaction procedure}

The transesterification was carried out in a batch reactor, equipped with thermostat, mechanical stirrer, condensation systems and a beaker of capacity $500 \mathrm{ml}$ on hot plate with magnetic stirrer. Soybean oil $(100 \mathrm{ml})$ was preheated to the desired temperature before starting the reaction. The $\mathrm{KOH}$ doped cement clinker-methanol solution was prepared freshly in order to maintain the catalytic activity and to prevent moisture absorbance. The methanolic solution was added to Soybean oil in the reaction flask and the measurement of time was started at this point. Experiment was allowed to prolong for $1 \mathrm{~h}$ at $65^{\circ} \mathrm{C}$ conduct to ensure the completion the conversion of the fatty acid into fatty acid methyl esters (FAMEs). The reaction mixture was allowed to cool down and equilibrate which resulted in separation of two phases. The upper phase consisted of alkyl esters, and the lower phase contained the glycerol.

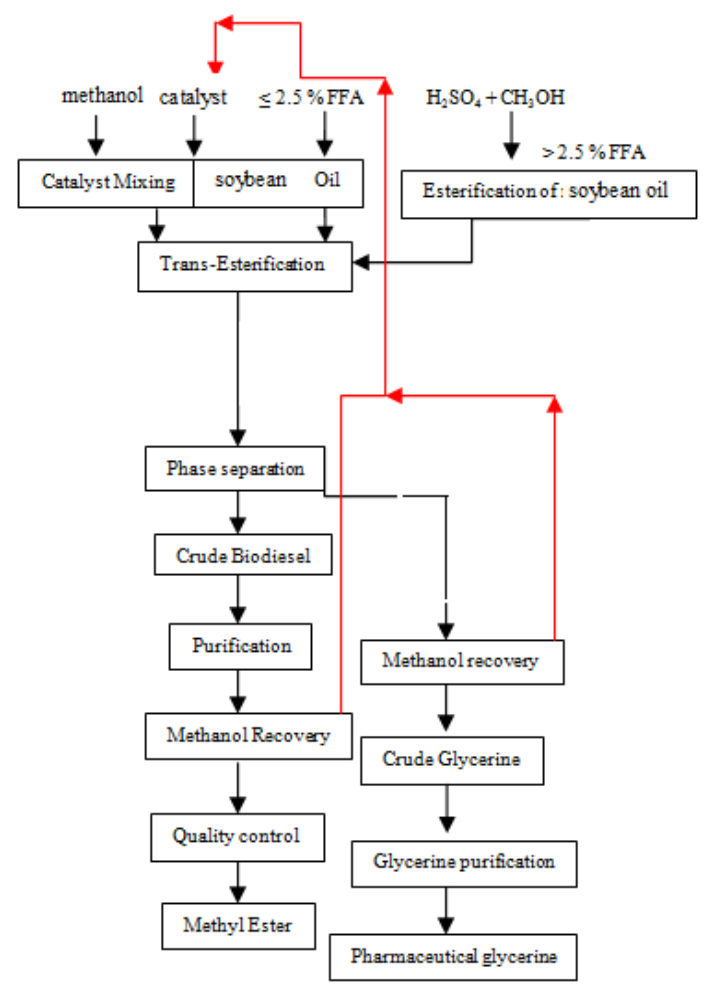

Figure 2. Schematic representation of biodiesel production

\section{Process description}

Schematic representation of biodiesel production has been shown in figure 2. The Esterification step is required if the oil is above $2.5 \%$ FFA. The production of biodiesel is divided into three processing: 
- A transesterification section where the vegetable oil is subject to chemical transesterification in order to produce fatty acid methyl esters (biodiesel) and co-product glycerol.

- A biodiesel purification section where the methyl esters are refined to meet the biodiesel specifications.

- A glycerol recovery section.

\section{Results and Discussion}

Transesterification of soybean oil was carried out with $21 \mathrm{wt} \% \mathrm{KOH} / \mathrm{Cement}$ clinker as a catalyst at the Reaction temperature of $65^{\circ} \mathrm{C}$ with $\mathrm{MeOH} /$ oil molar ratio of $6: 1$. It was found that by using of $\mathrm{KOH}$ doped cement clinker catalyst, the reaction yield was of $\leq 85$ $\%$ in $1 \mathrm{~h}$. With the increase in the concentration of catalyst, there was decrease in the yield of methyl esters. The characterization of biodiesel has shown in Table 3.

Table 3. Characterization of biodiesel

\begin{tabular}{ccc}
\hline S.NO. & Parameters & Biodiesel \\
\hline 1 & Kinematic viscosity $\left(\mathrm{cSt}\right.$ at $\left.40^{\circ} \mathrm{C}\right)$ & 13 \\
2 & Density $(\mathrm{kg} / \mathrm{l})$ & 0.812 \\
3 & Specific gravity $\left(\right.$ at $\left.26^{\circ} \mathrm{C}\right)$ & 0.875 \\
4 & Pour point $\left({ }^{\circ} \mathrm{C}\right)$ & -10 \\
5 & Cloud point $\left({ }^{\circ} \mathrm{C}\right)$ & -6 \\
6 & Flash point $\left({ }^{\circ} \mathrm{C}\right)$ & 170 \\
7 & Fire point $\left({ }^{0} \mathrm{C}\right)$ & 175 \\
8 & Yield $(\%)$ & 84.6 \\
\hline
\end{tabular}

\section{Conclusions}

The present study clearly showed that the $\mathrm{KOH}$ doped cement clinker is non-toxic, inexpensive, recyclable and promising eco-friendly catalysts. Cement clinker loaded with potassium hydroxide was found to be strong solid base catalyst for the transesterification of soybean oil with methanol. The catalyst with $21 \mathrm{wt} \% \mathrm{KOH}$ loaded on cement clinker and calcined at $650^{\circ} \mathrm{C}$ for $3 \mathrm{~h}$. When the reaction was carried out at $65^{\circ} \mathrm{C}$, with a molar ratio of methanol to soybean oil of $6: 1$, a reaction time $1 \mathrm{~h}$ and an agitation speed of 600 rpm, the highest conversion reached $\leq 85 \%$. The catalyst was recycled to study the reusability. Catalyst may be used at least for three times.

\section{Acknowledgments}

The authors express their thanks for the support from MNIT, Jaipur, Rajasthan, India and the staff of Chemical Engineering, Department of chemical engineering, MNIT. 


\section{References}

1. J.M. Marchetti, V.U. Miguel, A.F. Errazu, Heterogeneous esterification of oil with high amount of free fatty acids, Fuel 86, 906-910, 2007

2. Srivastava A, Prasad R. Triglycerides based diesel fuels, Renew Sustain Energy Rev 4,111-33, 2000

3. A. Murugesan, C. Umarani, T.R. Chinnusamy, M. Krishnan, R. Subramanian, N. Neduzchezhain, Production and analysis of bio-diesel from non-edible oils-A review, Energy Rev, doi:10.1016/j.rser.2008.02.003

4. M.A. Dubé, A.Y. Tremblay, J. Liu, Biodiesel production using a membrane reactor, Bioresource Technology 98,639-647, 2007.

5. W. Xie, Z. Yang, Ba-ZnO catalysts for soybean oil transesterification, Catalysis Letters $117,159-165,2007$

6. E.W. Eckey, Esterification and interesterification, JAOCS 33,575-579,1956

7. N. Dizge, C. Aydiner, D.Y. Imer, M. Bayramoglu, A. Tanriseven, B. Keskinler, Biodiesel production from sunflower, soybean, and waste cooking oils by transesterification using lipase immobilized onto a novel microporous polymer, Bioresource Technology 100, 1983-1991, 2009

8. V. Sivozhelezova, D. Bruzzeseb, L. Pastorinoa, E. Pechkova, C. Nicolini, Increase of catalytic activity of lipase towards olive oil by Langmuir-film immobilization of lipase, Enzyme and Microbial Technology 44,72-76, 2009

9. B. Freedman, E.H. Pryde, T.L. Mounts, Variables affecting the yields of fatty esters from transesterified vegetable oils, Journal of the American Oil Chemists Society 61, 1638-1643, 1984

10. M. Canakci, J. Van Gerpen, Biodiesel production via acid catalysis, Transactions of the American Society of Agricultural Engineers 42, 1203-1210, 1999

11. S.L. Dmytryshyn, A.K. Dalai, S.T. Chaudhari, Synthesis and characterization of vegetable oil derived esters: evaluation for their diesel additive properties, Bioresource Technology 92, 55-64, 2004

12. O.J. Alamu, M.A. Waheed, S.O. Jekayinfa, Effect of ethanol-palm kernel oil ratio on alkalicatalyzed biodiesel yields, Fuel 87, 1529-1533, 2008

13. Formo MW. Ester reactions of fatty materials. J Am Oil Chem Soc 31(11), 548-59, 1954

14. Feuge RU, Gros At., Modification of vegetable oils, VII Alkali catalyzed interesterification of peanut oil with ethanol. J Am Oil Chem Soc 26 (3),97, 1949

15. Krishangkura K, Simamaharnnop R. Continuous transmethylation of palm oil in an organic solvent. J Am Oil Chem Soc 69(2), 166-9, 1992

16. Saka S, Dadan K. Bio diesel fuel, from rapeseed oil as prepared in supercritical methanol. Fuel 80, 22, 2001.

17. M.A. Dubé, A.Y. Tremblay, J. Liu, Biodiesel production using a membrane reactor, Bioresource Technology 98, 639-647, 2007

18. B. Freedman, E.H. Pryde, T.L. Mounts, Variables affecting the yields of fatty esters from transesterified vegetable oils, Journal of the American Oil Chemists Society 61, 1638-1643, 1984

19. G. Vicente, M. Martínez, J. Aracil, Optimization of integrated biodiesel production, part I. a study of the biodiesel purity and yields, Bioresource Technology 98, 1724-1733, 2007

20. F. Ma, M. Hanna, Bioresour. Technol. 70, 1, 1999

21. A.K. Dalai, M.G. Kulkarni, L.C. Meher, Biodiesel productions from vegetable oils using heterogeneous catalysts and their applications as lubricity additives, IEEE EIC Climate Change Technology Conference EICCCC art 4057358, 2006 
22. F.R. Abreu, D.G. Lima, E.H. Hamú, S. Einloft, J.C. Rubim, P.A.Z. Suarez, New metal catalysts for soybean oil transesterification, JAOCS Journal of the American Oil Chemists' Society 80 , 601-604, 2003

23. M.L. Granados, M.D.Z. Poves, D.M. Alonso, R. Mariscal, F.C. Galisteo, R. Moreno- Tost, J. Santamaría, J.L.G. Fierro, Biodiesel from sunflower oil by using activated calcium oxide, Applied Catalysis B: Environmental 73, 317-326, 2007

24. L. Wang, J. Yang, Transesterification of soybean oil with nano-MgO or not in supercritical and subcritical methanol, Fuel 86, 328-333, 2007

25. J. Jitputti, B. Kitiyanan, P. Rangsunvigit, K. Bunyakiat, L. Attanatho, P. Jenvanitpan- jakul, Transesterification of crude palm kernel oil and crude coconut oil by different solid catalysts, Chemical Engineering Journal 116,61-66, 2006

26. W. Xie, X. Huang, Synthesis of biodiesel from soybean oil using heterogeneous $\mathrm{KF} / \mathrm{ZnO}$ catalyst, Catalysis Letters 107, 53-59, 2006

27. T.F. Dossin, M.-F. Reyniers, R.J. Berger, G.B. Marin, Simulation of heterogeneously MgOcatalyzed transesterification for fine-chemical and biodiesel industrial production, Applied Catalysis B 67, 136-148, 2006 